\title{
Sentence Recognition Error of Hearing-Impaired Elderly in Background Noise and Time Alteration: Case Analysis
}

\author{
Wondo Na', Gibbeum Kim¹, Gungu Kim', Jihyeon Lee, Woojae Han² \\ 'Department of Speech Pathology and Audiology, Graduate School, Hallym University, Chuncheon, Korea \\ ${ }^{2}$ Division of Speech Pathology and Audiology, Research Institute of Audiology and Speech Pathology, College of Natural Sciences, \\ Hallym University, Chuncheon, Korea
}

\author{
배경 소음 및 말속도 변화에 따른 난청 노인의 문장인지도 오류: 사례분석을 중심으로 \\ 나원도 ${ }^{1}$ 김기쁨 ${ }^{1}$ 김건구 ${ }^{1}$ 이지현 ${ }^{1}$ 한우재 ${ }^{2}$ \\ 한림대학교 일반대학원 언어병리청각학과', 한림대학교 자연과학대학 언어청각학부, 청각언어연구소 ${ }^{2}$
}

\begin{abstract}
Purpose: Although many previous studies related to sentence recognition of the hearing-impaired elderly have found their poor performance under various distracting listening conditions, there is still a lack of information for their error type in the sentence. The purpose of present study was to analyze a prominent error type among nine parts of speech in various levels of noise and fast speech conditions for the hearing-impaired elderly. Methods: Seven old listeners with moderate sensorineural hearing loss participated. For estimating their sentence recognition, Korean Speech Perception in Noise was applied for four signal-to-noise ratios (no noise, $+6,+3,0 \mathrm{~dB}$ ) and four time alteration conditions $( \pm 30 \%, \pm 15 \%)$, while being presented at the most comfortable level to each participant. Total percent error and substitution error patterns of the sentence recognition were analyzed as a function of conditions. Results: The percent error of sentence recognition was increased as either noise level increased or speech rate was faster. Among the parts of speech, noun substitution error pattern showed the highest number for all participants regardless levels of noise and time alteration. Interestingly, the noun substitution error pattern was outstood in quiet and $15 \%$ time compression. Conclusion: Results of the present study suggest that aural rehabilitation of the hearing-impaired elderly may focus on reducing and correcting the noun substitution error to improve their sentence recognition.
\end{abstract}

Key Words: Sentence recognition, Noun substitution error, Hearing-impaired elderly, Signal-to-noise ratios, Time alteration.

Received: September 2, 2016 / Revised: October 2, 2016 / Accepted: October 5, 2016

Correspondence: Woojae Han, \#8603, Natural Science Building, College of Natural Sciences, Hallym University, 1 Hallimdaehak-gil, Chuncheon 24252, Korea Tel: +82-33-248-2216 / Fax: +82-33-256-3420 / E-mail: woojaehan@hallym.ac.kr

\section{INTRODUCTION}

최근 통계청의 인구통계학 자료에 따르면, 국내의 65세 이상 고령 인구는 전체 인구의 약 $13.1 \%$ 로써, 2030년에는 전체 인구 의 $28.4 \%, 2060$ 년에는 $40.1 \%$ 로 고령 인구의 비율이 빠르게 상 승할 것으로 전망하고 있다(Statistics Korea, 2016). 이러한 분 석 결과는 일본, 미국, 독일 등 선진국들과 비교하여 가장 단기 간 내에 가장 높은 고령인구 비율을 갖게 될 것이고, 국가차원 에서 고령사회에 대한 철저한 준비가 필요함을 시사하고 있다 (Kim \& Yeo, 2015). 그 중 노인의료복지사업과 관련하여, 노인
들의 3대 만성 질환 중 하나인 노인성난청은 현재 65 74세의 노인들 중 25 40\%, 75세 이상의 노인들 중 약 $70 \%$ 가 경험하 고 있는 것으로 평가되어 빠른 증가세를 보이는 고령 인구 비율 과 더불어 추정한다면, 국내 노인성난청 환자 수는 수년 내에 상당히 많아질 것으로 예측한다.

노인성난청의 가장 두드러진 특징은 청력 역치의 상승, 소음 속에서 어음인지 능력의 저하, 중추청각기관의 음향정보처리 능 력 및 방향성 분별 능력의 저하 등이다(Gates \& Mills, 2005). 특히 가장 일반적인 노인성난청의 청력도 형태인 2,000 4,000 $\mathrm{Hz}$ 고주파수 영역에서의 1차적인 청력 손실은 말 지각 시 매우 
중요하게 작용하는 무성 자음의 변별 능력 저하의 2 차적 손실 을 초래하여(Spoor, 1967), 노인성난청 환자들의 대부분은 보청 기 착용 후에도 소리는 크게 들리지만 무슨 소리인지 정확히 이 해하기 어렵다고 표현한다(Hanratty \& Lawlor, 2000).

그럼에도 불구하고, 일상생활에서 말소리를 듣고 이해하는 것은 조용한 환경보다는 대부분 다양한 소음환경 속에서 이루 어진다. 소음환경 속에서 상대방의 말소리, 즉 문장을 듣고 이 해하는 것은 말초 및 중추 청각 기능과 인지 기능을 통한 복잡 한 처리과정을 필요로 하기 때문에(Schneider et al., 2010) 노 인성난청 환자들은 일상생활에서의 효과적인 의사소통이 어렵 다(Ciorba et al., 2012). 그 예로써, 청자의 연령이 증가함에 따 라 단어 및 문장 인지도의 저하는 수많은 선행연구들을 통해 검증되어 왔다. 소음속문장인지(speech perception in noise, $\mathrm{SPIN)}$ 검사를 활용하여 건청성인, 건청노인, 난청노인의 소음 하 문장인지도를 측정한 Pichora-Fuller et al.(1995)의 연구 결 과를 살펴보면, 동일한 배경 소음 조건에서 세 그룹 중 난청노인 그룹의 점수가 가장 저조하게 나타났다. Jokinen(1973)도 +22 , $+12,+2,-3 \mathrm{~dB}$ SNR의 소음 조건에서 연령 증가에 따른 어음 인지도를 검사하였고, 배경소음이 증가할수록 난청노인에게서 어음인지 능력이 빠르게 감소함을 보여주었다. 또한 다화자소 음 속에서 일음절어를 이용하여 소음 하 단어인지도를 측정한 Wilson \& Strouse(2002)의 연구 결과에서도 유사한 수행도를 나타내기 위해서는 건청성인과 난청노인은 평균 6 9 dB SNR 차이를 보였다. 이러한 결과는 일상생활에서 난청노인의 소음 하 문장인지도를 측정한 Killion et al.(2004)의 연구결과에서 도 잘 뒷받침해 주었다. Quick speech-in-noise 검사 시, 난청 노인은 건청성인과 비교하여 평균 $5 \mathrm{~dB}$ SNR 더 높은 신호대 잡음비를 필요로 하였고, 이는 소음 속에서 어음을 이해하는 능력이 청력은 물론 연령과도 상관관계가 높음을 시사하였다 (Vermeire et al., 2015).

앞서 언급한 대로 노인들은 노화에 따른 시간적 처리능력의 저하로 인해 말소리 이해의 어려움, 특히 빠른 말속도에서 어음 인지의 어려움을 겪는다(Wingfield et al., 1985). 이러한 어려움 은 말초 및 중추 기관의 청각처리능력 및 인지적 처리능력의 저 하로 분석된다(Schneider et al., 2010). Han et al.(2013) 연구에 서는 건청성인 20명을 대상으로 말속도 조절 하에서 선택적 단 어 강조 유무에 따른 문장인지도를 측정하였다. 7가지 말속도 변화 조건 $( \pm 60 \%, \pm 40 \%, \pm 20 \%, 0 \%)$ 중 $60 \%$ 압축 조건을 제 외하고는 나머지 6 가지 조건들에서 높은 정반응률을 보였다. 이 와 동일한 실험 조건을 만 65 85세 노인 17명에게 적용한 Cho et al.(2014)의 연구 결과에서는 말속도 압축률이 증가할수록 건청성인과 비교 시 더 낮은 문장인지도를 보였으며, 이는 건청 노인이라도 말속도가 빨라질수록 어음인지에 어려움을 보인다
고 결론내렸다. 젊은 성인, 중년층, 노인을 대상으로 실시한 Vaughan \& Letowski(1997)의 연구에서도 압축률이 증가할수 록 연령이 높을수록 더 낮은 어음인지도를 보여 선행연구 간 결과의 일치성을 나타내었다. Gordon-Salant(2007)는 Revised $\mathrm{SPIN}$ 을 사용하여 건청성인과 노인, 난청성인과 노인으로 이루 어진 네 그룹을 대상으로 보통의 말속도와 $50 \%$ 압축률을 갖은 문장을 사용하여 문장인지도를 평가하였다. 보통의 말속도에 서는 네 그룹 모두 $94 \%$ 이상의 우수한 수행력을 보였지만, $50 \%$ 압축률을 적용한 문장에서는 난청노인의 경우 $64 \%$ 의 정 반응률을 보였다.

종합해 보면, 난청노인의 어음인지도에 많은 영향을 미치는 배경소음의 정도와 말속도 변화에 따른 문장인지도는 이미 다 수의 연구자들에 의해 분석되고 있지만, 구체적으로 문장의 구 성요소 중 어느 부분에서 오류를 두드러지게 보이는지에 대한 연구는 국내외적으로 미비한 실정이다(Chun et al., 2015). 최근 난청 정도 및 유형을 고려하여 어음인지 오류를 확인하고 오류 유형을 분석해야 한다는 연구자들이 등장하고 있다. Ferguson et al.(2014)은 난청인이 특별히 어려워하는 음소를 찾아 청능훈 련에 적용할 것을 강조하였고, Kim et al.(2014) 또한 음소의 오 류에 따른 재활계획을 수립하면 더욱 효율적인 재활이 이루어 질 것이라고 주장하였다. 그럼에도 난청유형에 따른 어음인지 의 오류결과를 분석하기에는 비슷한 청력손실의 유형 및 형태 를 갖은 난청인들 간 어음인지의 개인차가 크기 때문에 획일화 된 오류유형을 관찰하기 어렵다(No \& Lee, 2012). 그러나 빠르 게 증가하는 노인성난청 환자들의 어음인지력 향상을 위한 구체 적인 재활 전략이 수립되기 위해서는 자주 발생되는 오류를 분 석하고자 하는 시도와 이를 바탕으로 효율적인 청능재활 프로 그램을 위한 근거를 제시하여야 한다(Han et al., 2016). 이러한 맥락에서 본 사례 연구는 난청노인의 말 지각 시 부정적인 영 향을 미치는 배경소음과 말속도 변화에 따라 문장인지의 오류 를 품사별로 분석하고 확인하여 추후 난청노인들에게 실질적 인 재활 방법이 될 수 있는 구체적인 연구를 제안하고자 한다.

\section{MATERIALS AND METHODS}

\section{연구 대상}

서울에 거주하는 만 65세 이상 노인 7명(남성 4명, 여성 3명) 을 대상으로 실험을 진행하였다. 대상자의 평균 연령은 78세였 고, 표준편차는 4.79였다. 연구 대상자는 과거 이과적 병력이 없 었으며 한국형 간이정신상태검사(Korea version of mini-mental state examination, MMSE-K) (Kwon \& Park, 1989) 시 모 두 25점 이상의 점수를 보여 인지기능의 정상 여부를 확인하 였다. 
연구 대상자의 청력선별검사 결과는 고막운동도 검사 시 $\mathrm{A}$ 유형으로 모두 정상이었고, 순음청력검사 시 기도역치평균은 청 력이 좋은 쪽 귀를 기준으로 $45 ~ 55 \mathrm{~dB} \mathrm{HL}$ 의 중도의 감각신경 성난청을 보였다. 또한 좋은 쪽 귀를 기준으로 어음인지도의 평 균은 $82 \%$, 표준편차는 0.13 이었다. 7 명의 연구대상자들의 보청 기 착용 기간은 평균 73.14 개월, 표준편차는 26.09였다(Table 1).

연구에 참여 전 대상자들은 연구 목적 및 절차에 대하여 충 분한 설명을 듣고 이해한 후 연구 참여에 대한 동의서에 서명 을 하였다. 또한 모든 연구에 대한 절차 및 내용은 한림대학교 생명윤리위원회로부터 승인을 받았다(HIRB-2015-027).

\section{자극음}

본 연구를 위해 자극음으로 한국형 소음하문장인지(Korean Speech Preception In Noise, K-SPIN) (Kim et al., 2000) 검 사의 문장목록을 그대로 사용하였다. 그러나 각 문장 뒤에 따 라오는 부가의문문이 목표단어의 또 다른 단서가 될 수 있고, 문장 전체를 듣고 따라말하기 방식의 검사 진행을 위해 각 문 장 뒤에 붙은 부가의문문을 제거한 후 사용하였다. 또한 본 연 구에서는 소음하문장인지 검사의 각 목록당 개발된 40 문항을 $1 / 2$ 인 20 문항씩 나누어 기존 6 개의 검사목록을 총 12 개 목록 으로 재설정하였다. 소음하문장인지 검사의 12 개의 목록 내 문 항들은 목표단어를 예측하기 쉬운 문장(low predictability)과 어려운 문장(high predictability) 각각 10 개씩 동일하게 포함시 켰다. 따라서 문장의 난이도가 적절하게 배분된 한국형 소음하 문장인지 검사의 고유의 목적에 부합하고 난이도가 결과에 미 치는 영향을 최소화하였다. 완성된 최종 검사목록은 조용한 상황과 $+6,+3,0 \mathrm{~dB} \mathrm{SNR}$ 의 3 가지 다화자소음 상황의 총 네 가지 조건을 적용하였다. 부가의문문 제거 및 문장 내 실효값 (root mean square)의 조절을 위해 Adobe Audition 프로그램 (Ver. CC2014.2; Adobe Systems Complex, San Jose, CA, USA)을 사용하였다.
말속도 변화에 따른 문장인지 검사를 위해서는 빠른 속도로 압축한 문장(30\% 압축), 조금 빠른 속도로 압축한 문장 $(15 \%$ 압축), 조금 느린 속도로 확장한 문장(15\% 확장), 느린 속도로 확장한 문장( $30 \%$ 확장)의 총 네 가지 조건으로 Adobe Audition 프로그램을 사용하여 음원 제작을 하였다. 이 과정에서 적용된 말속도 변화 외에 말소리의 주파수나 다른 자질은 변화 시키지 않고 문장 내, 문장 간 동일한 실효값으로 조절하여 제 작된 음원의 음량을 고르게 조정하였다.

총 8개의 소음과 말속도 변화 조건에서 검사 목록을 무작위 순서로 적용하여 연구 대상자에게 실험을 진행하였으나, 소음 의 정도 및 말속도 변화는 쉬운 상황에서 어려운 상황(예, 조용 한 상황 $\rightarrow 0 \mathrm{~dB} \mathrm{SNR}, 30 \%$ 확장 $\rightarrow 30 \%$ 압축)으로 모든 연구대 상자에게 동일하게 검사를 진행시켜 대상자가 조건변화에 당황 하지 않고 실험에 참여할 수 있도록 유도하였다.

\section{연구 절차}

소음하문장인지 검사와 말속도 변화에 따른 문장인지 검사 모두 방음부스 내의 스피커를 이용하여 검사를 실시하였다. 대 상자는 방음실 내에서 한 개의 스피커와 $1 \mathrm{~m}$ 떨어진 곳에서 스 피커를 마주하고 보청기를 착용하지 않은 상태에서 검사를 실 시하였다. 문장 제시 강도는 대상자의 쾌적역치수준(most comfortable level)에서 제시하였고, 7명의 쾌적역치수준은 60 90 dB HL이었다.

콤팩트 디스크 플레이어(Samsung, Seoul, Korea)를 이용하 여 검사 문장을 제시하고 연구 대상자가 제시된 문장을 듣고 따 라 말하면, 검사자는 대상자의 응답을 듣고 정답을 채점하였다. 검사의 지속시간에 따른 피로도와 수행력의 영향을 최소화하고 자 세 명의 대상자는 소음하문장인지 검사를 먼저, 나머지 네 명의 대상자는 말속도 변화에 따른 문장인지 검사를 먼저 실시 하였다.

Table 1. Subjects' information and their hearing status

\begin{tabular}{|c|c|c|c|c|c|c|c|c|c|c|c|c|c|c|c|c|c|}
\hline & \multirow{3}{*}{ Gender } & \multirow{3}{*}{$\begin{array}{c}\text { Age } \\
\text { (years) }\end{array}$} & \multicolumn{12}{|c|}{ Hearing sensitivity (dB HL) } & \multirow{2}{*}{\multicolumn{2}{|c|}{$\begin{array}{c}\text { Word } \\
\text { recognition } \\
\text { scores }(\%)\end{array}$}} & \multirow{3}{*}{$\begin{array}{l}\text { Experience of } \\
\text { hearing aid } \\
\text { (months) }\end{array}$} \\
\hline & & & \multicolumn{2}{|c|}{$0.25 \mathrm{kHz}$} & \multicolumn{2}{|c|}{$0.5 \mathrm{kHz}$} & \multicolumn{2}{|c|}{$1 \mathrm{kHz}$} & \multicolumn{2}{|c|}{$2 \mathrm{kHz}$} & \multicolumn{2}{|c|}{$4 \mathrm{kHz}$} & \multicolumn{2}{|c|}{$8 \mathrm{kHz}$} & & & \\
\hline & & & $\mathrm{R}$ & $\mathrm{L}$ & $\mathrm{R}$ & $\mathrm{L}$ & $\mathrm{R}$ & $\mathrm{L}$ & $\mathrm{R}$ & $\mathrm{L}$ & $\mathrm{R}$ & $\mathrm{L}$ & $\mathrm{R}$ & $\mathrm{L}$ & $\mathrm{R}$ & $\mathrm{L}$ & \\
\hline S1 & $\mathrm{F}$ & 77 & 55 & 50 & 55 & 55 & 55 & 55 & 55 & 60 & 60 & 65 & 65 & 70 & 78 & 78 & 96 \\
\hline S2 & M & 75 & 55 & 70 & 45 & 80 & 55 & 70 & 55 & 70 & 50 & 80 & 60 & 80 & 94 & 94 & 77 \\
\hline S3 & M & 87 & 65 & 55 & 60 & 45 & 60 & 45 & 70 & 55 & 75 & 70 & 95 & 110 & 40 & 90 & 60 \\
\hline S4 & $\mathrm{F}$ & 77 & 45 & 45 & 45 & 45 & 45 & 45 & 45 & 45 & 40 & 45 & 65 & 70 & 88 & 82 & 24 \\
\hline S5 & M & 81 & 45 & 30 & 50 & 40 & 50 & 50 & 50 & 45 & 55 & 55 & 75 & 65 & 80 & 70 & 72 \\
\hline S6 & $\mathrm{M}$ & 72 & 40 & 45 & 40 & 45 & 45 & 55 & 50 & 50 & 50 & 55 & 55 & 50 & 56 & 62 & 75 \\
\hline S7 & $\mathrm{F}$ & 77 & 60 & 70 & 55 & 75 & 55 & 60 & 50 & 50 & 55 & 50 & 55 & 70 & 60 & 100 & 108 \\
\hline Mean & & 78.00 & 52.14 & 52.14 & 50.00 & 55.00 & 52.14 & 54.28 & 53.57 & 53.57 & 55.00 & 60.00 & 67.14 & 73.57 & 71 & 82 & 73.14 \\
\hline $\mathrm{SD}$ & & 4.79 & 9.06 & 14.39 & 7.07 & 16.07 & 5.67 & 8.86 & 8.02 & 8.99 & 10.80 & 12.24 & 14.09 & 18.41 & 0.19 & 0.13 & 26.09 \\
\hline
\end{tabular}




\section{자료 분석}

문장인지도 검사의 점수 산출방법은 스피커를 통해 연구대 상자의 쾌적수준에서 문장을 들려주고 연구 대상자가 똑같이 따라 말하게 한 후 정반응의 개수를 세어 백분율로 나타내었 다. 검사자는 연구 대상자가 따라 말하는 것을 들으면서 문장 내에서 정확하게 반응하는 단어수와 목록 내의 문장수를 백분 율로 점수화하였다. 즉, 문장을 구성하는 단어 및 조사가 하나 라도 틀리면 오반응으로 간주하였고, 각 조건당 문장 수는 20 개로 구성하였다.

자료 분석 시 검사자가 정확하게 오류를 분석하였는지 확인 하기 위해 연구 대상자의 반응을 녹음하여 분석하였고, 청각학 을 전공하는 석사과정 연구원 2명 모두 오류라고 판단하면 최 종 오류로 체점하였다. 평가자 간 신뢰도(inter-rater reliability) 는 카파계수 $\mathrm{K}=0.783$ ( $p=0.000)$ 으로 평가자 간의 높은 동의 의 정도를 확인하였다. 다양한 오류 중 일관성 있는 오류유형을 심도있게 분석하기 위해, 먼저 문장을 구성하는 단어를 우리말 의 9품사(명사, 대명사, 수사, 동사, 형용사, 관형사, 부사, 조사, 감탄사)로 구분하고 대치로 인한 오류만을 분류하였다. 본 연 구에서 적용한 대치란 목표낱말에 있는 특정 음소(목표 음소) 를 다른 음소(대치 음소)로 바꾸어 산출하는 오류이며(Kim \& Shin, 2010), '가방’을 ‘바방'이라고 산출하는 것으로 목표음소 / ㄱ/을 /비으로 대치한 것으로 분석하였다.

\section{RESULTS}

\section{문장 전체의 오류}

7명의 연구 대상자의 문장 전체의 평균 오류율은 Figure 1에 제시하였다. 소음하문장인지 검사에서는 신호대잡음비가 점차 낮아질수록 오류율은 점차 높아졌다. 조용한 환경에서는 $21.67 \%,+6 \mathrm{~dB}$ 에서는 $28.67 \%,+3 \mathrm{~dB}$ 에서는 $34.00 \%$ 로 오류율
이 완만히 상승하다가 $0 \mathrm{~dB}$ 에서는 $52.00 \%$ 로 오류율이 가장 높았다(Figure 1A). 예측도가 낮은 문장의 평균 오류율은 예측 도가 높은 문장의 오류율과 비교 시 모든 신호대잡음비 조건에 서 전체적으로 약 3 4\%(range: 2.67 4.67\%) 더 높았다.

말속도 변화에 따른 문장인지 검사 결과, $30 \%$ 확장조건에서 는 $25.67 \%$ 로 오류율이 가장 낮았고, $30 \%$ 압축조건에서는 $53.67 \%$ 로 오류율이 가장 높았다. 그러나 $15 \%$ 확장과 $15 \%$ 압 축조건에서는 각각 $36.00 \%$ 와 $35.67 \%$ 로 비슷하게 오류율이 나 타났다(Figure 1B). 예측도가 낮은 문장의 오류율은 예측도가 높은 문장의 오류율과 비교 시, $30 \%$ 및 $15 \%$ 압축과 $15 \%$ 확장 조건에서 약 4 5\% 더 높았으나, 30\% 압축조건에서는 두 문장 의 오류율 차이가 $1 \%$ 정도로 예측도의 구분이 미비하였다.

\section{품사에 따른 대치 오류}

Figure 2에 소음하문장인지 검사 결과, 7명의 연구 대상자 각 각의 대치오류 수를 9 개의 품사별로 분석하여 제시하였다. 대 상자간 개인차는 있었지만, 가장 높은 대치 오류를 보인 품사 는 명사였다.

연구 대상자 S1은 조용한 상황에서 명사 대치오류를 14개, 동 사 대치오류를 1 개, 부사 대치오류를 1 개 보여주었다. 배경 소 음이 증가하는 $+6,+3,0 \mathrm{~dB}$ 에서도 각각 $14,8,5$ 개로, 명사 대 치오류가 다른 품사 대치오류 수에 비하여 월등히 높았다. 그러 나 소음도가 높아질수록 명사 대치오류 수는 점차 줄어드는 경 향을 보였다. 명사 대치오류 외에, $+6 \mathrm{~dB}$ 에서는 동사 대치오류 1 개와 조사 대치오류 1 개가 나타났다. $+3 \mathrm{~dB}$ 에서 오류대치는 동사 1 개, 형용사 1 개, 조사 1 개를 보였고, $0 \mathrm{~dB}$ 에서는 형용사 와 부사에서 대치오류를 각각 1 개씩 나타냈다. 연구 대상자 S2 는 명사 대치오류를 조용한 상황, $+6,+3,0 \mathrm{~dB}$ 에서 각각 6,13 , 5,1 개씩 보여주었다. 조용한 상황과 비교하여 배경 소음이 있는 $+6 \mathrm{~dB}$ 에서 두 배 정도의 명사 대치오류 수를 보이다가 소음이
Figure 1. Group mean for percent error of sentence recognition as a function of background noise levels $(A)$ and time alterations (B). Error bars mean standard deviation. HP: high predictability, LP: low predictability.
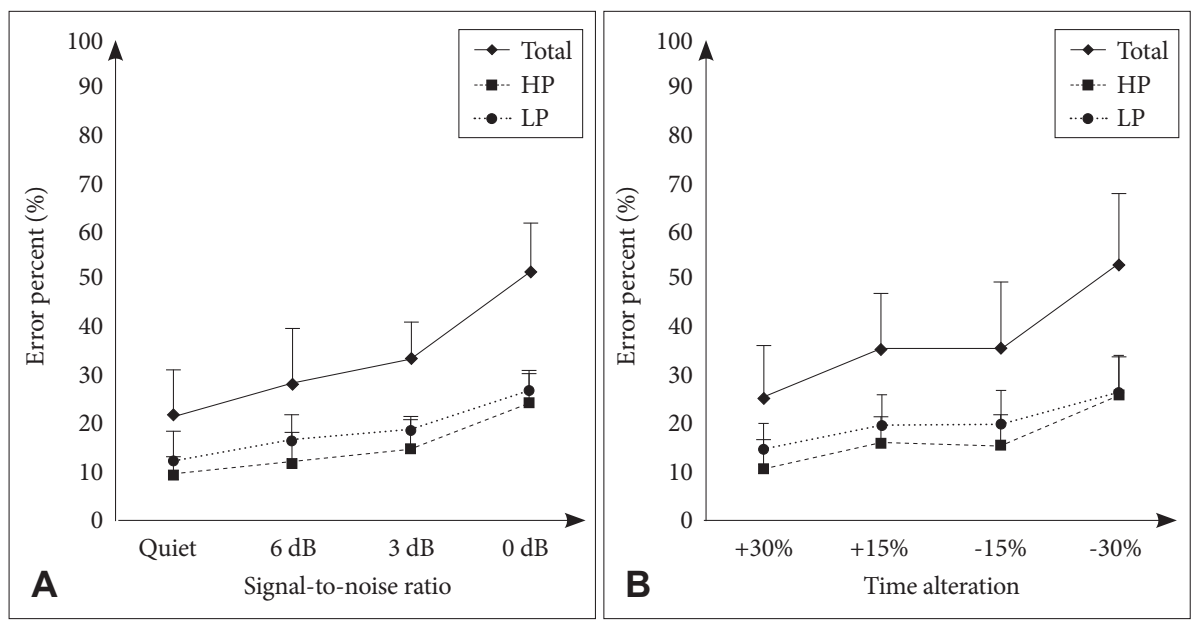


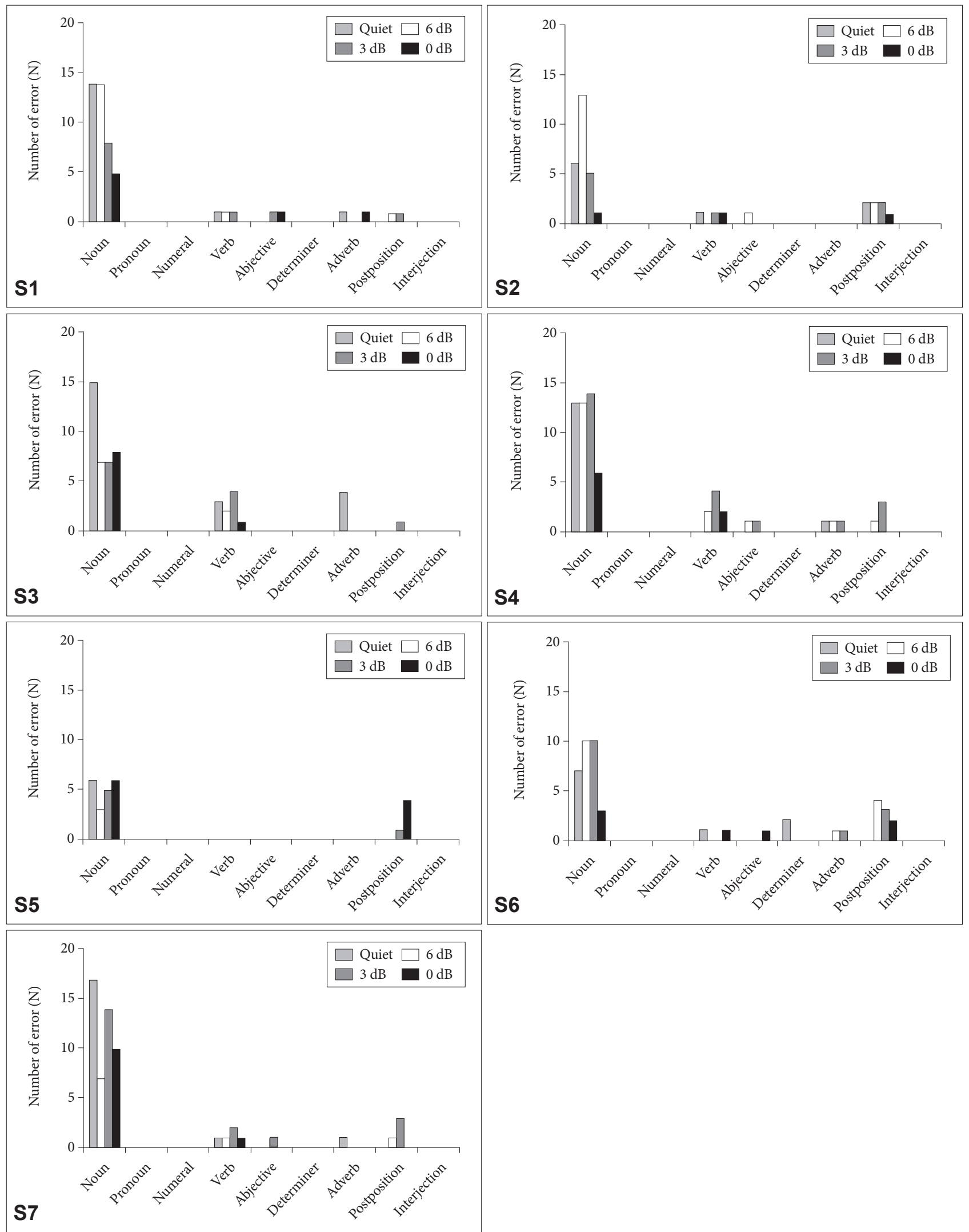

Figure 2. Individual substitution error of nine parts of speech in various signal-to-noise ratio. The S1-S7 mean seven subjects participated in the study. 
더 높아지는 +3 과 $0 \mathrm{~dB}$ 에서는 대치오류 수가 확연히 감소하였 다. 다른 품사의 대치오류는 동사, 형용사, 조사에서 각각 1 2 개씩 배경 소음의 정도와 상관없이 산재되어 나타났다. 연구 대 상자 S3 역시 명사 대치오류를 가장 두드러지게 보여주었다. 조 용한 상황에서는 15 개로 가장 많았고, $+6,+3,0 \mathrm{~dB}$ 에서 각각 $7,7,8$ 개를 나타내었다. 다른 연구 대상자와 비교 시, 동사 대치 오류 수가 더 많았다. 조용한 상황, $+6,+3,0 \mathrm{~dB}$ 에서 각각 3,2 , 4,1 개를 보여주었다. 부사 대치오류는 조용한 상황에서만 4 개 를 보였다. 연구 대상자 $\mathrm{S} 4$ 는 명사 대치오류를 각 상황에서 13 , $13,14,6$ 개 나타냈다. 그 외에 두드러진 대치오류는 $+3 \mathrm{~dB}$ 조건 에서 동사 4 개, 조사 3 개를 보여 다른 신호대잡음비 조건보다 는 $+3 \mathrm{~dB}$ 에서 대치로 인한 오류가 확연했다. $\mathrm{S} 5$ 의 경우, 7 명의 연구 대상자들 중 가장 적은 어음인지 오류를 보였으나, 여전히 명사 대치오류는 각 상황에서 $6,3,5,6$ 개로 가장 높게 나타내 어 중도의 감각신경성 난청노인에게서 보이는 높은 명사 대치 오류 결과에 대한 일관성을 지지하였다. 연구 대상자 $\mathrm{S} 6$ 은 명사 대치오류에서 각 상황별로 7, 10,10,3개를 보여주었고, 역시 소음이 가장 높은 $0 \mathrm{~dB}$ 에서 가장 적은 명사 대치오류를 나타 냈다. 그러나 조사 대치오류가 $+6,+3,0 \mathrm{~dB}$ 에서 각각 $4,3,2$ 개 를 보여 다른 연구 대상자보다 많은 조사 대치오류 수를 보여주 었다. 그 외에 동사, 형용사, 관형사 대치오류가 1 2개 나타났 다. 연구 대상자 S7은 명사 대치오류 수가 조용한 상황에서 17 개로 가장 많다가 $+6 \mathrm{~dB}$ 에서는 7 개로 확연히 줄어들었다. 그러 나 +3과 $0 \mathrm{~dB}$ 에서는 다시 명사 대치오류 수가 많아져서 14,10 개를 나타내었다. 그 밖에 동사 대치오류는 배경 소음 정도에 상관없이 모든 상황에서 1 2개 정도 나타났고, 형용사, 부사, 조사 대치오류 수도 소수 존재하였다. 종합적으로, 7 명의 연구 대상자에서 공통적으로 명사 대치오류가 다른 품사의 대치오 류보다 크게 두드러졌고, 그 중 세 명의 연구 대상자(S1, S3, S7) 은 조용한 상황에서도 높은 명사 대치오류 수를 보여주었다. 반면, 신호대잡음비가 가장 낮은 $0 \mathrm{~dB}$ 에서는 모든 연구 대상자 들이 명사 대치오류 수가 가장 적게 나타났다.

Figure 3은 말속도 변화에 따른 문장인지 검사 결과를 연구 대상자별로, 9 개의 품사 종류 별로 대치 오류 수를 분석하여 제시하였다. Figure 2의 결과와 유사하게 말속도 변화조건에서 도 명사가 가장 높은 대치 오류수를 보여주었다. 연구 대상자 S1 은 9품사 종류 중 명사 대치오류 수를 가장 많이 나타내었다. 특히 $30 \%$ 확장과 $15 \%$ 확장 조건에서 명사 대치오류를 7 개씩 나타내었으나, $15 \%$ 압축조건에서 14 개의 명사와 5 개의 동사 대 치오류 수를 보여주었다. $30 \%$ 압축조건에서 다시 명사 대치오 류 수가 감소하여 6개를 나타냈다. 동사, 관형사, 부사, 조사 등 에서 1 2개의 대치오류가 소수로 나타났다. 연구 대상자 S2, $\mathrm{S} 5, \mathrm{~S} 6$ 는 명사 및 타 품사 대치오류 수에서 비슷한 유형을 보여
주었다. 즉, 명사 대치오류 수가 타 품사에 비해 가장 높았고, 그 수는 공통적으로 5 6개로 말속도 빠르기에 무관하게 비슷 하게 나타났다. 더불어 동사, 형용사, 부사, 전치사에서 대치오 류 수가 말속도 변화 조건에서 소수로 산재되어 나타났다. 연구 대상자 S3 역시 명사 대치오류가 가장 많았으나, $30 \%$ 확장과 $15 \%$ 압축조건에서 12 개를, $15 \%$ 확장과 $30 \%$ 압축에서는 각각 9 개와 6 개를 나타냈다. 그 외에 동사 대치오류가 $30 \%$ 확장과 $15 \%$ 확장에서 각각 4 개와 5 개로 높았다. 한편, 연구 대상자 S4 는 $15 \%$ 확장 및 압축, $30 \%$ 압축조건에서 명사 대치오류 수가 $16,16,15$ 개로 가장 높았고, 흥미롭게도 $15 \%$ 압축조건에서 4 개 의 조사 대치오류 수를 보였다. 연구 대상자 S7은 7명의 연구 대 상자들 중 명사 대치오류 수가 가장 높았다. $30 \%$ 및 $15 \%$ 확장, $15 \%$ 및 $30 \%$ 압축조건에서 각각 $14,10,10,16$ 개의 명사 대치오 류 수를 보여주었고, $30 \%$ 확장 및 압축조건에서 각각 3 개의 동 사 대치오류를 나타냈다. 종합해보면, 말속도 변화에 따른 문 장인지 검사에서도 타 품사에 비하여 명사 대치오류 수가 현저 히 높았고, 타 품사 대치오류는 소수로 보여졌다. 그 중 연구 대 상자 S7을 제외하고, 6 명의 연구 대상자에서는 $15 \%$ 압축조건 에서 명사 대치오류 수가 가장 높았다.

\section{DISCUSSIONS}

본 연구는 배경 소음의 정도와 말속도 변화에 따른 7명의 난 청노인들을 대상으로 문장인지도를 측정하고, 그중 가장 많이 오류를 범하는 대치 품사를 확인하고자 하였다.

선행연구의 결과와 동일하게 어려운 듣기 조건에서 문장의 오류율은 더 높게 나타났다. 즉, 신호대잡음비가 낮아질수록 혹은 말속도가 빨라질수록 문장 전체의 오류율과 예측도가 높 거나 낮은 문장에서 모두 오류율이 점차 상승하였다(GordonSalant et al., 2007; Pichora-Fuller et al., 1995). 흥미로운 것 은 배경 소음이 커지면 예측도가 높은 문장의 오류율이 예측 도가 낮은 문장의 오류율보다 더 적어져, 난청노인들이 배경 소 음 상황에서 문장의 단서가 되는 정보를 활용하는 것으로 확인 할 수 있었지만(Needleman \& Crandell, 1995), 30\% 압축의 빠른 말속도에서는 이러한 단서가 문장인지도 향상에 도움이 되지 않는 것으로 나타났다. 이는 말초적 청력손실보다 노화로 인한 요소가 난청노인들의 시간처리결함에 더 크게 작용하였 고(Strouse et al., 1998), 시간적 민감성(temporal sensitivity)에 서 노화로 인한 차이가 연속된 문맥에서 더 크게 작용할 수 있 음을 보여주었다(Fitzgibbons et al., 2006).

본 연구의 핵심결과로 배경 소음 정도 혹은 말속도 변화에 무관하게 7명의 난청노인들에게서 모두 명사 대치오류가 가장 두드러졌다. 명사는 사물의 이름을 나타내는 단어로 품사의 형 

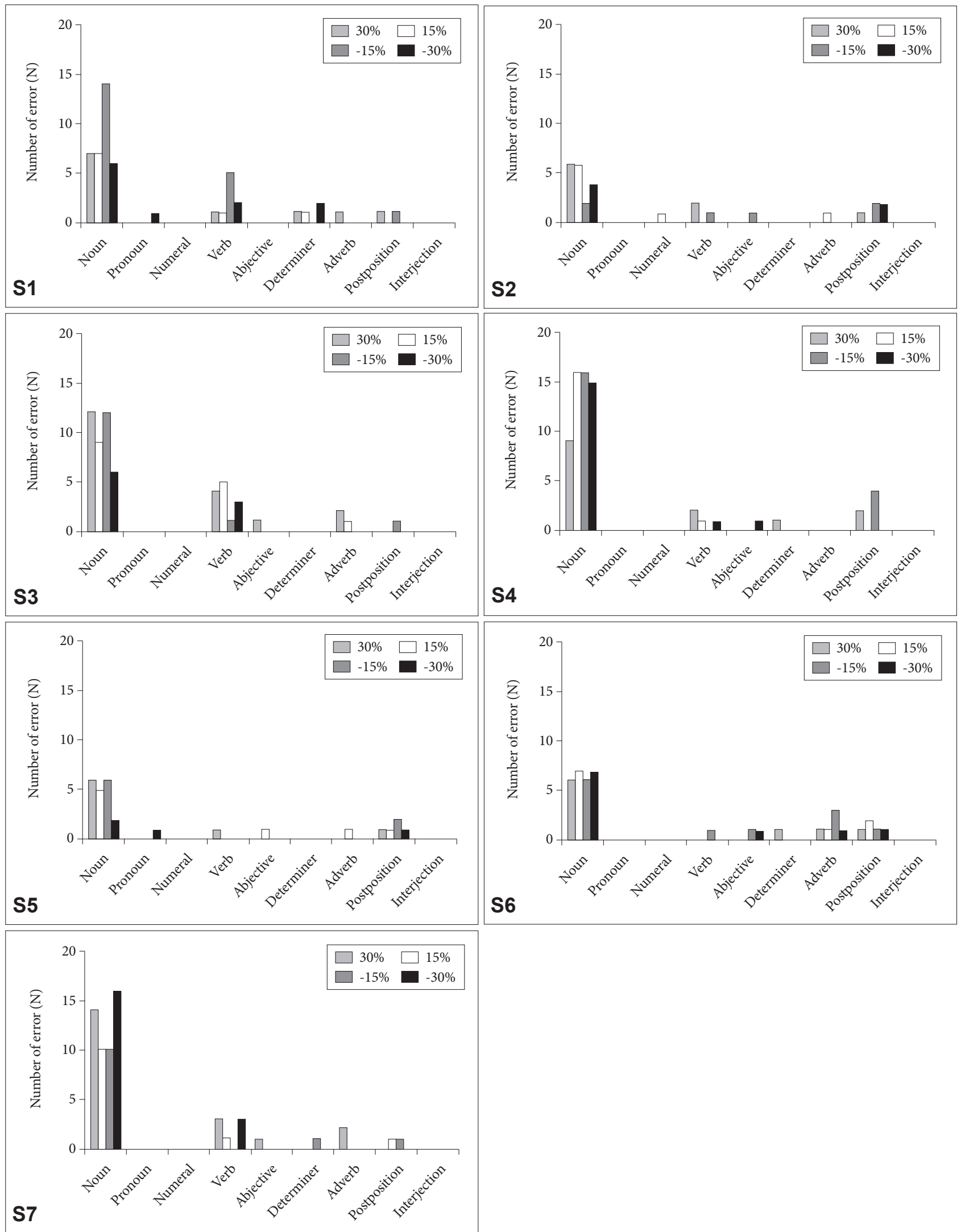

Figure 3. Individual substitution error of nine parts of speech in various time alteration conditions. The S1-S7 mean seven subjects participated in the study. 
태에 변화가 없으며, 주어 및 목적어 혹은 부사어도 될 수 있지 만 타품사에 비해 주어 역할이 크다(Hong, 2002). 이에 반해, 다른 품사들은 문장 내에서 문맥에 따라 쉽게 유추하거나 듣 고 따라 말하기에 무리가 없어 상대적으로 오류가 적은 것으로 판단되었다. 따라서 다른 품사에 비해 문장의 의미를 전달하는 가장 핵심적인 역할을 하는 명사의 오류가 높다면 노인들의 말 지각 시 가장 부정적인 영향을 줄 수 있다. 본 연구에 참여한 7 명의 중도의 감각신경성 난청노인들의 구체적인 명사 대치오류 의 예는 일반화하기에 어려움이 존재하였다. 이음절의 명사 중 앞 음절에서 대치오류를 범하는 '한문 $\rightarrow$ 단문, '탐정 $\rightarrow$ 공정', 뒷 음절의 대치오류를 보이는 '시장 $\rightarrow$ 시전', '희경 $\rightarrow$ 희영'은 물론, 앞 뒤 음절 모두 대치오류를 범하는 '정리 $\rightarrow$ 종이', '폭탄 $\rightarrow$ 발판' 등 그 종류가 획일화하기에는 각 개인의 어휘력, 교육 수준, 생활 수준 등 고려해야 할 사항이 많이 존재하였다(Park, 2016). 본 연구의 결과는 No \& Lee(2012)의 난청성인을 대상으로 단음 절 인지 연구 결과에서 보여준 자·모음 음절의 높은 초성 대치 수와 모·자음 음절의 높은 종성 대치 수와는 상이하였다. 즉, 일상생활에서 대화 시 주로 사용하는 문장의 경우 초성 혹은 종성의 획일적인 대치오류보다는 문맥상 이해하고 추측하기 때 문에 일음절만 제시되었을 경우와 달리 대치오류의 형태를 정 형화하기 어렵다.

소음이 없는 조용한 상황이 배경 소음도가 높은 상황보다는 문장 전체의 오류율이 적었지만, 조용한 상황에서도 명사 대치 오류가 높다는 것은 추후 재활의 적용가능성이 높음을 시사하 였다. 또한 본 연구에서 말속도에 따른 문장인지도에서 $15 \%$ 빠 른 말속도에서 7명의 연구 대상자들이 공통적으로 명사 대치 오류가 가장 높았음을 고려한다면, 말속도가 조금 빨라도 명사 대치오류를 중점적으로 재활한다면 어음인지도의 상승을 기대 해 볼 수 있겠다.

본 연구는 실험 설계에서 두 개의 제한점을 갖고 있다. 첫째, 새로이 재설정된 한국형 소음하문장인지 검사의 12 개의 목록 간 동질성 확인이 필요하다. 목록 간 난이도 및 문장의 길이의 일관성을 확인하여 결과를 이끌었다면 본 연구 결과를 일반화 하기에 보다 무리가 없었을 것이다. 둘째, 8개의 실험 조건에 대 하여 검사 목록 12 개를 무작위로 적용하였기에, 연구대상자 간 동일한 목록이 아니어서 발생되는 품사의 수 차이가 명사 대치 오류 수의 차이로 연결되었을 가능성을 배제할 수 없다. 따라 서 추후 후속연구에서는 이러한 문제점을 보완하고 연구 대상 자의 수를 늘려 일반화를 이끌 수 있는 방법으로 진행해야 하 겠다. 또한 연구 대상자의 수용소음레벨(acceptable noise level) 과 대치가 가장 많이 발생되는 소음도의 상관성을 살펴보는 것 도 흥미로운 결과를 보일 것으로 기대한다. 예를 들어, S5의 경 우, $0 \mathrm{~dB}$ 조건에서 명사 및 조사 대치오류 수가 가장 높게 나타
나 조용한 상황에서 높은 명사 오류 수를 보인 다른 연구 대상 자들보다 수용소음레벨이 높지 않을까 한다. 향후 후속 연구를 통하여 수용소음레벨 수치가 높은 난청노인에게 목표 어음으 로부터 문장 내의 단서를 활용하거나(Baek \& Lee, 2012) 해당 소음 정도에서 명사 대치오류를 수정하는 청능훈련이 유의미 한 변화를 보이는지 확인하는 것이 필요하겠다.

중심 단어 : 문장인지·명사 대치오류·난청노인·신호대잡음비· 시간변화.

\section{Acknowledgments}

본 논문은 2015년 대한민국 교육부와 한국연구재단의 지원을 받 아 수행된 연구입니다(NRF-2015S1A3A2046760).

\section{REFERENCES}

Baek, E. J. \& Lee, J. H. (2012). Measurement of acceptable noise level and self-reported subjective disability in adult cochlear implant users. Audiology, 8(2), 196-203.

Cho, S., Yu, J., Chun, H., Seo, H., \& Han, W. (2014). Speech perception in older listeners with normal hearing: Conditions of time alteration, selective word stress, and length of sentences. Korean Journal of Audiology, 18(1), 28-33.

Chun, H., Ma, S., Han, W., \& Chun, Y. (2015). Error patterns analysis of hearing aid and cochlear implant users as a function of noise. Journal of Audiology and Otology, 19(3), 144-153.

Ciorba, A., Bianchini, C., Pelucchi, S., \& Pastore, A. (2012). The impact of hearing loss on the quality of life of elderly adults. Clinical Interventions in Aging, 7(6), 159-163.

Ferguson, M. A., Henshaw, H., Clark, D. P., \& Moore, D. R. (2014). Benefits of phoneme discrimination training in a randomized controlled trial of 50-to 74-year-olds with mild hearing loss. Ear and Hearing, 35(4), el10-e121.

Fitzgibbons, P. J., Gordon-Salant, S., \& Friedman, S. A. (2006). Effects of age and sequence presentation rate on temporal order recognition. The Journal of the Acoustical Society of America, 120(2), 991-999.

Gates, G. A. \& Mills, J. H. (2005). Presbycusis. The Lancet, 366(9491), 11111120.

Gordon-Salant, S., Fitzgibbons, P. J., \& Friedman, S. A. (2007). Recognition of time-compressed and natural speech with selective temporal enhancements by young and elderly listeners. Journal of Speech, Language, and Hearing Research, 50(5), 1181-1193.

Han, W. (2012). Case study of speech perception in presbycusis. Audiology, $8,116-122$.

Han, W., Chun, H, Kim, G., \& Jin, I. (2016). Substitution patterns of phoneme errors in hearing aid and cochlear implant users. Journal of Audiology and Otology (In Press).

Han, W., Yu, J., \& Cho, S. (2013). Perception of time-altered sentences and selective word stress by normal-hearing listeners. The Journal of the Acoustical Society of Korea, 32(5), 430-437.

Hanratty, B. \& Lawlor, D. A. (2000). Effective management of the elderly hearing impaired-a review. Journal of Public Health, 22(4), 512-517.

Hong, S. I. (2002). Development of phonological awareness in Koran children. Communication Sciences and Disorders, 7(1), 49-64.

Jokinen, K. (1973). Presbyacusis: VI. Masking of speech. Acta Oto-Laryngologica, 76(1-6), 426-430.

Killion, M. C., Niquette, P. A., Gudmundsen, G. I., Revit, L. J., \& Banerjee, S. (2004). Development of a quick speech-in-noise test for measuring signal-to-noise ratio loss in normal-hearing and hearing-impaired listeners. The Journal of the Acoustical Society of America, 116(4), 23952405. 
Kim, D., Kim, J., \& Lee, K. (2014). Analysis of error characteristics and usabilities for Korean consonant perception test. Journal of Rehabilitation Research, 18(4), 295-314.

Kim, J. S., Pae, S. Y., \& Lee, J. H. (2000). Development of a test of Korean speech intelligibility in noise (KSPIN) using sentence materials with controlled word predictability. Journal of Speech Science, 7(2), 37-50.

Kim, S. \& Shin, J. Y. (2010). Articulatory and Phonological Disorder. Seoul: Sigma Press.

Kim, S. H. \& Yeo, S. G. (2015). Presbycusis. Hanyang Medical Reviews, 35(2), 78-83.

Kwon, Y. C. \& Park, J. H. (1989). Korean version of Mini-Mental State Examination (MMSE-K). Part I: Development of the test for the elderly. Journal of Korean Neuropsychiatric Association, 28(1), 125-135.

Needleman, A. R. \& Crandell, C. C. (1995). Speech recognition in noise by hearing-impaired and noise-masked normal-hearing listeners. Journal-American Academy of Audiology, 6, 414-424.

No, B. I. \& Lee, J. H. (2012). A comparison study of monosyllable recognition in listeners with sloping versus flat hearing loss types. Audiology, $8,78-86$.

Park, S. (2016). The reliability and validity of world health organization quality of life assessment instrument in elderly patients with hearing loss: Depending on use of hearing aid. Audiology and Speech Research, 12(2), 74-81.

Pichora-Fuller, M. K., Schneider, B. A., \& Daneman, M. (1995). How young and old adults listen to and remember speech in noise. The Journal of the Acoustical Society of America, 97(1), 593-608.

Schneider B. A., Pichora-Fuller M. K., \& Daneman M. (2010). The effects of senescent changes in audition and cognition on spoken language comprehension. In S. Gordon-Salant, R. D. Frisina, A. N. Popper, R. R. Fay (Eds.). Springer Handbook of Auditory Research: The Aging Auditory System: Perceptual Characterization and Neural Bases of Presbycusis (pp. 167-
210). New York, NY: Springer.

Spoor, A. (1967). Presbycusis values in relation to noise induced hearing loss. International Audiology, 6(1), 48-57.

Statistics Korea. (2016). Dependency ratio and aged-child ratio. Retieved from http://kosis.kr/statHtml/statHtml.do?orgId=101\&tblid=DT_2K AA202\&vw_cd=MT_RTITLE\&list_id=ZTIT_B\&scrId=\&seqNo= \&lang_mode=ko\&obj_var_id=\&itm_id=\&conn_path $=$ E1 $\&$ path $=\% 2$ 5EC\%25A3\%25BC\%25EC\%25A0\%259C\%25EB\%25B3\%2584\%2520 \%25EA\%25B5\%25AD\%25EC\%25A0\%259C\%25ED\%2586\%25B5\%25 EA\%25B3\%2584\%2520\%253E\%2520\%25EC\%259D\%25B8\%25EA\%2 5B5\%25AC\%252C\%2520\%25EA\%25B0\%2580\%25EA\%25B5\%25AC \%25EB\%25B6\%2580\%25EC\%2596\%2591\%25EB\%25B9\%2584\%2520 \%25EB\%25B0\%258F\%2520\%25EB\%2585\%25B8\%25EB\%25A0\%25B9 \%25ED\%2599\%2594\%25EC\%25A7\%2580\%25EC\%2588\%2598

Strouse, A., Ashmead, D. H., Ohde, R. N., \& Grantham, D. W. (1998). Temporal processing in the aging auditory system. The Journal of the Acoustical Society of America, 104(4), 2385-2399.

Vaughan, N. E. \& Letowski, T. (1997). Effects of age, speech rate, and type of test on temporal auditory processing. Journal of Speech, Language, and Hearing Research, 40(5), 1192-1200.

Vermeire, K., Knoop, A., Boel, C., Auwers, S., Schenus, L., Talaveron-Rodriguez, M., et al. (2015). Speech recognition in noise by younger and older adults effects of age, hearing loss, and temporal resolution. Annals of Otology, Rhinology and Laryngology, 125(4), 297-302.

Wilson, R. H. \& Strouse, A. (2002). Northwestern University Auditory Test No. 6 in multi-talker babble: A preliminary report. Journal of Rehabilitation Research and Development, 39(1), 105-114.

Wingfield, A., Poon, L. W., Lombardi, L., \& Lowe, D. (1985). Speed of processing in normal aging: Effects of speech rate, linguistic structure, and processing time. Journal of Gerontology, 40(5), 579-585. 